Vladimir Klimenko ${ }^{1}$, Vladimir Matskovsky ${ }^{2 *}$, Dittmar Dahlmann ${ }^{3}$

${ }_{1}^{1}$ Moscow Power Engineering Institute, Moscow, Russia; e-mail: nilgpe@mpei.ru

2 Institute of Geography, Russian Academy of Sciences, Moscow, Russia;

e-mail: matskovsky@igras.ru

* Corresponding author

${ }^{3}$ Rhenish Friedrich-Wilhelm University, Bonn, Germany; e-mail: d.dahlmann@uni-bonn.de

\title{
MULTI-ARCHIVE TEMPERATURE
}

RECONSTRUCTION OF THE RUSSIAN

\section{ARCTIC FOR THE PAST TWO MILLENNIA}

ABSTRACT. We present a multi-archival mean annual quantitative temperature reconstruction for Northeastern Europe covering the period of the past two millennia based on tree-ring, pollen, and historical data. This reconstruction was developed primarily to build up a comparative chronology of climatic and historical events in the study region. Five different calibration and verification approaches were used. A comparison of mean decadal temperature reconstruction for Northeastern Europe with those for larger regions and the Hemisphere shows that larger climatic events were visible both in the whole Northern Hemisphere and its separate regions. Less significant climatic events on a regional level may differ considerably from the overall climate signature on the hemispheric level. Highest pre-industrial mean annual temperatures in $A D$ 981-990 were $1,0^{\circ} \mathrm{C}$ warmer and lowest in $A D$ 1811-1820 were $1,3^{\circ} \mathrm{C}$ colder than average in AD 1951-1980. The new reconstruction shows much higher degree of variability as compared to Panarctic and hemispheric reconstructions.

KEY WORDS: climate change, Arctic, palaeogeography, temperature reconstruction, multi-proxy, historical climatology

\section{INTRODUCTION}

A link between climatic and cultural changes is particularly strong in marginal areas of human inhabitance, such as arid areas (steppes, deserts, and semideserts) and highlatitude regions like Northeastern Europe. There is a vast body of literature on this subject, ascending to Antiquity, in particular, to the works of Aristotle, Theophrastus, and Hipparchus. During the recent decades, studies of this subject have gained in scope in connection with a massive breakthrough in the field of earth sciences and, in particular, knowledge of the past climates. This has resulted in numerous papers concerning the role of climate in the fate of the various states [see, e.g. Klimenko, 2009; Aimers, Hodell, 2011; Bbntgen et al., 2011]. A study of a possible impact of climate change on the historical process in the Northeastern Europe makes its first steps. However, before one can come to the well-grounded conclusions it is necessary to obtain a high-resolution climatic evidence for a given region for the whole historical period. The main goal of this study is reconstruction of the regional decadal annual temperature variability for the last 2000 years.

\section{STUDY AREA}

The study area comprises a region limited by the Kola Peninsula in the west $\left(40^{\circ} \mathrm{E}\right)$, Chelyuskin Cape (Taimyr Peninsula) to the east $\left(104^{\circ} \mathrm{E}\right)$, and the $60^{\circ} \mathrm{N}$ latitudinal line in the south (Fig. 1).

The western boundary of the study area is determined by the territory, which Novgorodians started to master in the early twelfth century - it was the time when they 


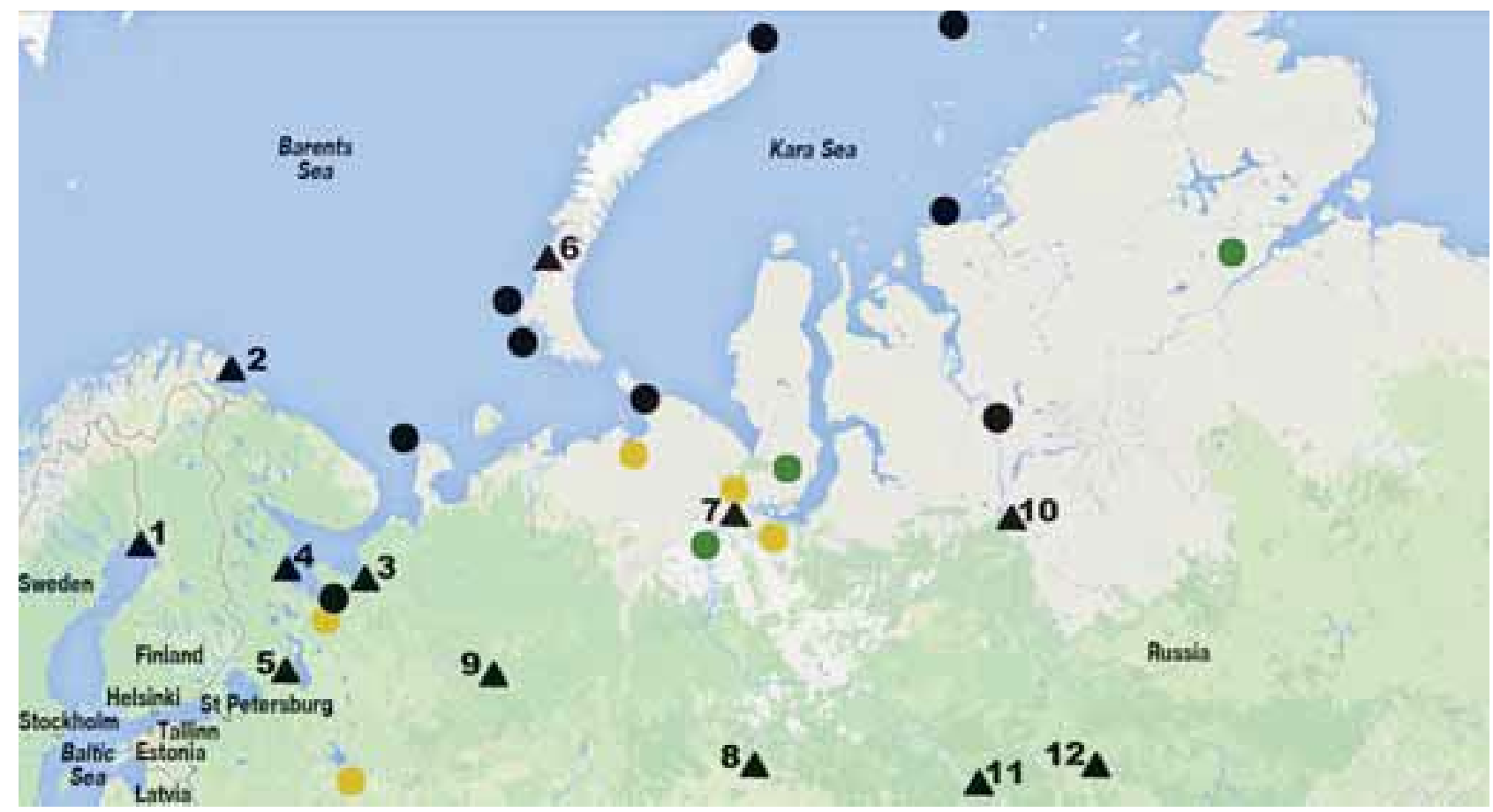

Fig. 1. The map of the study area showing locations of proxy climatic chronologies. Lake-sediment (yellow), tree-ring (green), and major historical (black) evidence. The locations of the long-term meteorological stations within and around the study area (triangles): (1) Haparanda; (2) Vardw; (3) Arkhangelsk; (4) Kem; (5) Petrozavodsk; (6) Malye Karmakuly; (7) Salekhard; (8) Tobolsk; (9) Syktyvkar; (10) Turukhansk; (11) Tomsk; (12) Yeniseysk

first settled on the right bank of the Severnaya Dvina which meant, in fact, the onset of the northeastern territories colonization. An eastern boundary is determined by the main historical scene in a period spanning from the mid-eleventh through the late seventeenth century. On this scene, specifically Taimyr was that natural boundary which could not be crossed through all this time. In this study, we also used some proxy climate data for the adjacent area just beyond the study region. On the one hand, it is connected with a sufficient correlation of remote temperature fields and, on the other hand, with the uniqueness of these data that contain important information.

The principal purpose of this study was the development of a climate reconstruction spanning the past two millennia based on all available proxy data. As the most of exploited proxy data (pollen and historical) represent mean annual air temperature, it is the mean annual temperature that was eventually reconstructed.

Moreover, because of the paucity of the high-resolution paleoclimatic evidence in the study region we focus on the mean decadal temperature reconstruction that, in fact, corresponds quite well to the principal purpose of building-up a comparative chronology of climatic and historical events. The matter is that human society responds, as a rule, not to a separate albeit significant interannual climate variations, but to more stable excursions with characteristic times comparable to the life expectancy of a human generation (20-22 yr). However, one should take into account that the employed tree-ring data represent only the warm season temperatures. Nevertheless, it doesn't decrease their value because of the well-established correlation between mean annual and summer temperatures, at least, in the study area. Thus, in this paper, we have used tree-ring data, as well as pollen and historical evidence, as proxy climatic data.

\section{MATERIALS, METHODS, AND RESULTS}

\section{Proxy data}

Various proxy data may have different time resolution. For instance, pollen data rarely achieve resolution better, than 


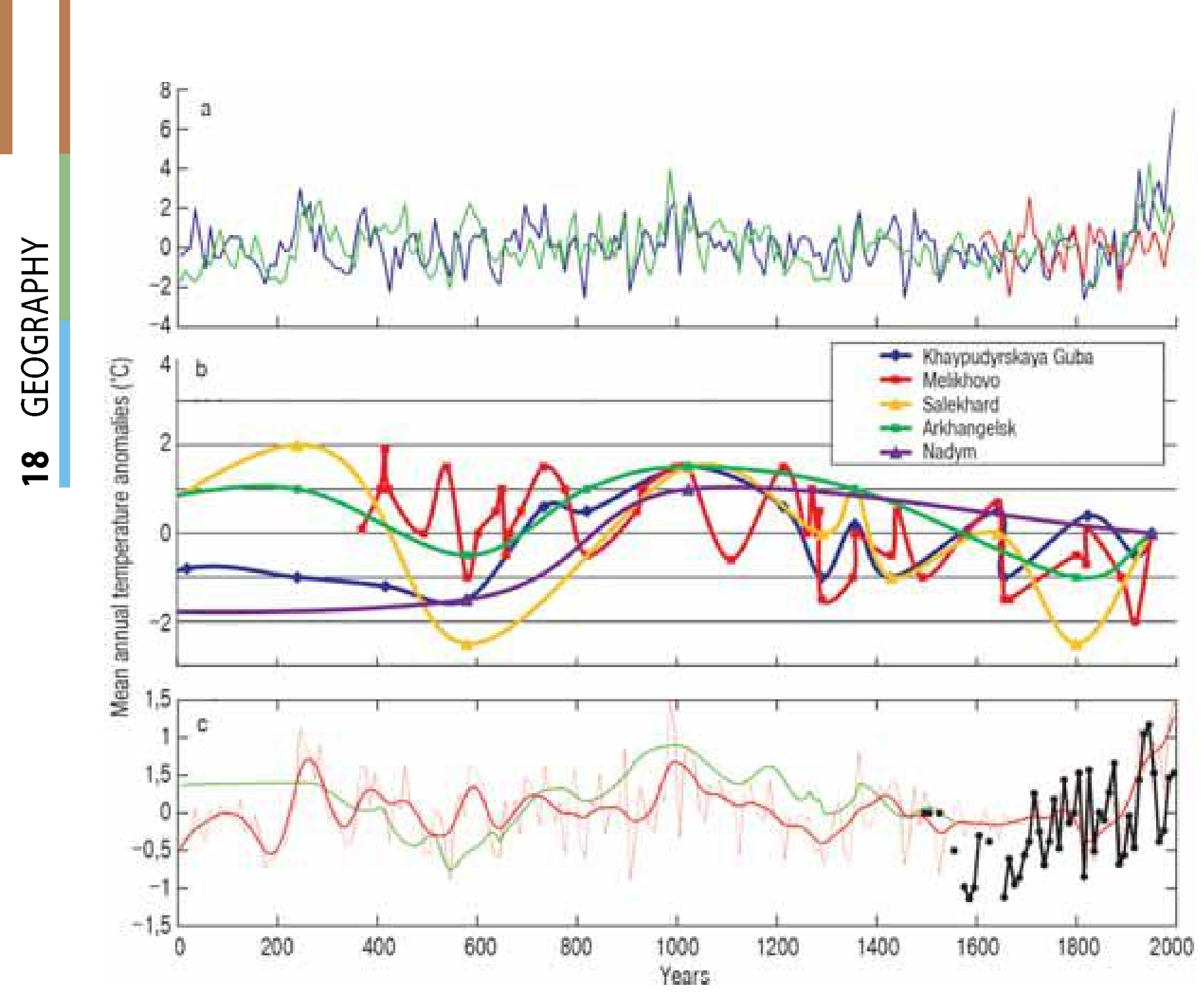

Fig. 2.

a) Variations of tree-ring width for Yamal (blue) [Hantemirov, Shiyatov, 2002], Taymyr (green) [Naurzbaev et al, 2002] and Polar Urals (red) [Gurskaya et al., 2012].

b) Estimated mean annual temperature anomalies based on pollen data [Klimanov et al., 1995; Velichko et al., 1997; Andreev, Klimanov, 2000].

c) Averaged proxy climatic data: pollen (green), tree-ring (red), historical (black) [Klimenko, 2010]. Here and elsewhere, temperature departures are expressed with reference to the period 1951-1980

Table 1. Proxy data used to reconstruct climate of northeastern Europe

\begin{tabular}{|c|c|c|c|c|c|c|c|}
\hline $\begin{array}{l}\text { Type } \\
\text { of data }\end{array}$ & Location & $\begin{array}{c}\text { Recon- } \\
\text { structed } \\
\text { value }\end{array}$ & Longitude & Latitude & $\begin{array}{l}\text { Start } \\
\text { year }\end{array}$ & $\begin{array}{l}\text { End } \\
\text { year }\end{array}$ & Source \\
\hline Pollen & Nadym & Тг & 72 & 64 & 545 & 1555 & Velichko et al., 1997 \\
\hline Pollen & Melikhovo & Тг & 38 & 57 & 370 & 1555 & Klimanov et al., 1995 \\
\hline Pollen & Salekhard & $\mathrm{T}\ulcorner$ & 66 & 67 & 0 & 1555 & Velichko et al., 1997 \\
\hline Pollen & Arkhangelsk & Tг & 43 & 64 & 0 & 1555 & Velichko et al., 1997 \\
\hline Pollen & Khaypudyrskaya Guba & Тг & 60 & 68 & 0 & 1555 & $\begin{array}{l}\text { Andreev, Klimanov, 2000; } \\
\text { Velichko et al., } 1997\end{array}$ \\
\hline $\begin{array}{l}\text { Tree-ring } \\
\text { width }\end{array}$ & Yamal & Тл & 70 & 67 & 0 & 1995 & $\begin{array}{l}\text { Hantemirov, Shiyatov, } \\
2002\end{array}$ \\
\hline $\begin{array}{l}\text { Tree-ring } \\
\text { width }\end{array}$ & Taymyr & Тл & 102 & 72 & 0 & 1995 & Naurzbaev et al., 2002 \\
\hline $\begin{array}{l}\text { Tree-ring } \\
\text { width }\end{array}$ & Taymyr & Тл & 64 & 65 & 1605 & 1995 & Gurskaya et al., 2012 \\
\hline Historical & Northeastern Europe & Тг & $50-80$ & $65-80$ & 1495 & 1995 & Klimenko, 2010 \\
\hline
\end{tabular}


50 years, whereas tree-ring data allow a reconstruction with a resolution down to a year and even a season. Eventually, historical data may have a resolution within a day and even a few hours. However, with rising resolution an ability of proxy data to reconstruct long-term climatic variations decreases. This problem is well known for tree-ring data [Jones et al, 2009] and many methods to solve it were proposed. Today, scientific community shares an opinion that in order to develop a highquality reconstruction, one must employ both high- and low-resolution data. The former allow for a reconstruction of such short-lived events as temperature drops following strong volcanic eruptions and the latter allow for a correct reconstruction of the substantial climatic events amplitude [Klimenko, Sleptsov, 2003; Moberg et al, 2005; Jones et al, 2009].

With that said, in this work, we employed the following proxy data (Fig. 2):

1. Tree-ring data on annual ring width for a detailed reconstruction of short-term climatic events.

2. Pollen (lake sediment) data - to reconstruct a long-term climatic signal and refine its amplitude.

3. Historical data - potentially the most accurate and detailed source of climatic information but spanning just over 500 years. See Table 1 for the description of all proxy time series used in this study.

\section{Instrumental data}

To calibrate the reconstruction and verify its contemporary part we have employed averaged data from twelve long-term meteorological stations located within and around the study area (see Fig. 1). Observations at these stations started in the following years (in chronological order): Arkhangelsk-1813, Petrozavodsk - 1817, Syktyvkar - 1817, Vardш - 1829, Tobolsk 1829, Tomsk - 1837, Haparanda - 1860,
Kem - 1862, Yeniseysk -1871, Turukhansk 1881, Salekhard and Malye Karmakuly - 1886 (after Global Historical Climatology Network; [Peterson, Vose, 1997]). It should be noted that observations at the central for the study area stations - Salekhard and Malye Karmakuly commenced later, than on the others, only in AD1886. That is why, although we used all available observational data, but for calibration purposes only a portion of them, after AD 1886, was used (therefore, the first value in the decadal time series refers to AD 1895).

\section{Proxy data assimilation in order to develop a generalized reconstruction}

Before composing various proxy data, we had conducted averaging of each type of data. Decadally averaged tree-ring data are presented at Fig. 2c. The lake-sediment data before averaging were slightly chronologically corrected making use of the averaged dendroclimatic data. A need to correct the original radiocarbon datings arises from a relatively low accuracy of the radiocarbon method, which in the time span of this study (0-2000 AD) may exceed a century [Reimer et al, 2009]. Therefore, the major peaks of pollen data were brought into accord with the dendroclimatic extremes after smoothing with a 30-yr running mean. This procedure allowed us to correct the radiocarbon datings that have one to two orders of magnitude larger variance, than the dendrochronological, and also to take into account a possible peaks deviation due to a basically different resolution of various data. See Table 2 for data corrections.

A portion of the pollen data was rejected because of their low reliability. They include, in particular, the data covering the last 450 years because radiocarbon datings within this time frame are very inaccurate and may correspond even to different centuries [Reimer et al, 2009]. We have also rejected the Nadym data prior to AD 545, because the previous dated sample from this site is over 1,000 years older, and the interpolated values show reduced temperatures through 0-545 AD, whereas the data from other sites (non-interpolated) demonstrate centennial-scale variations of a 
Table 2. The lake-sediment radiocarbon dating correction using the tree-ring data

\begin{tabular}{|c|c|c|c|}
\hline $\mathrm{C}^{14}$ dating & $\begin{array}{c}\text { Tree-ring } \\
\text { dating correction }\end{array}$ & Event & $\begin{array}{l}\text { Anomaly } \\
\text { sign }\end{array}$ \\
\hline 241 & 265 & Roman optimum peak & + \\
\hline 580 & 545 & 1st millennium A.D. maximum cooling & - \\
\hline 734 & 735 & Early Middle Ages warming peak & + \\
\hline 820 & 815 & Early Viking Age cooling & - \\
\hline 1023 & 1000 & First peak of the Medieval climatic optimum & + \\
\hline 1108 & 1125 & Cool interval of the Medieval optimum & - \\
\hline 1213 & 1185 & Second peak of the Medieval optimum & + \\
\hline 1290 & 1295 & Grand solar activity minimum (Wolf minimum) & - \\
\hline 1356 & 1365 & Grand solar activity maximum & + \\
\hline 1429 & 1455 & Kuwae volcano eruption & - \\
\hline 1441 & 1505 & The Little Arctic optimum & + \\
\hline 1491 & 1555 & Onset of the Arctic cooling & \\
\hline
\end{tabular}

different sign. After this screening, all pollen data were weighted and averaged.

The datasets from the Arkhangelsk, Salekhard, and Nadym sites were assigned lower weights (0.5) because they are represented in lesser detail compared to the Melikhovo and Khaypudyrskaya Guba and, therefore, contain more interpolated, and not measured values.
The averaged pollen data are presented at Fig. 2c. During the data compiling process, we also considered variants of pollen data assimilation with no datings correction and no data weighting (i.e. all data averaging with equal weights). The reconstructions developed making use of different variants of pollen data assimilation are presented at Fig. 3 and discussed below.

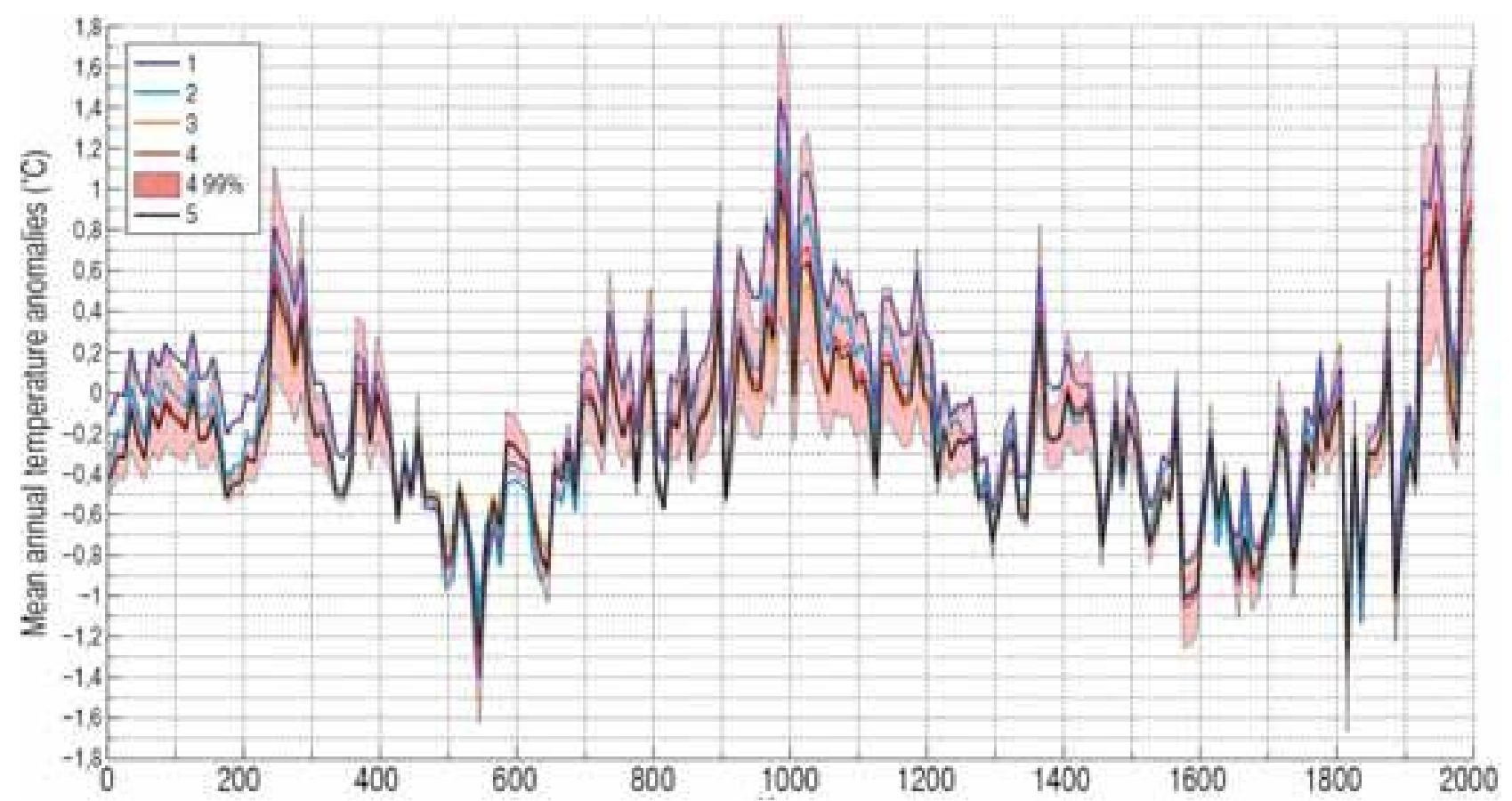

Fig. 3. Different versions of the reconstruction with various modifications of pollen data:

1) no dating correction and no weighting;2) with dating correction and weighting. Versions of the reconstruction with different calibration: 3) calibration on the instrumental period with the same mean and variation; 4) calibration on the instrumental period, linear regression, with 99\% confidence level; 5) calibration based on the arctic amplification effect and minimum values deduced from early instrumental data. Reference period: 1951-1980 


\section{Description of averaging and calibration}

For the final reconstruction, we used the Composite Plus Scaling (CPS) approach [Jones et al, 2009]. All selected proxy records from our network were assimilated in the following manner: the tree-ring data spanning the whole study period (1-1995 AD) were averaged with pollen (1-1555 AD) and historical (1495-1995 AD) data. The weights were taken equal.

Then we scaled the time series variance according to the known climate characteristics of the study area. Results of the past decade research show that Arctic amplification (larger temperature variability in the Arctic as compared to the variability for the Northern Hemisphere or the globe as a whole) varies within the range from 1,72 (relative to the instrumental data of the past one and a half centuries [Bekryaev et al, 2010]) to 3,4 (relative to the palaeodata through the past 3 million years [Miller et al, 2010] ). Winton [2006] found the mean annual Arctic warming, on the average, 1,9 times greater than the global mean based on a set of coupled climatic models. Our reconstructed value of the maximum temperature rise during the Medieval Warm Epoch is $1,1^{\circ} \mathrm{C}$; in comparison with a set of recent hemispheric temperature reconstructions [Klimenko, 2009; Moberg et al, 2005], it gives a value of Arctic amplification of 3,8 , which is quite close to the upper bound of the indicated range. Nevertheless, we found it useful to bring our reconstructed data to a full correspondence with the available palaeoclimatic evidence and adjust the peak temperature anomaly in the Medieval Warm Epoch to $1,0^{\circ} \mathrm{C}$. Because the temperatures at the maximum warmings (in the 980s and the 1940s) were by about $1^{\circ} \mathrm{C}$ above the reference $1951-1980$ baselines, we have preserved variance at the expense of lowering the minimum values. Finally, the minimum values in the 1810 s were set at $-1,3^{\circ} \mathrm{C}$ according to the early instrumental data from three meteorological stations: Haparanda, Arkhangelsk, and Petrozavodsk [Peterson, Vose, 1997]. Thus, we calibrated our reconstruction against both the palaeoclimatic and early instrumental data. Besides, we used a standard calibration against the target contemporary instrumental time series. This procedure comprises a calculation of the linear regression coefficients of the reconstructed against the instrumental data with the subsequent correction of the former. We have also employed an alternative calibration approach when variation and mean of reconstructed values are set equal to those of the instrumental data. This calibration approach seems to be preferable to an ordinary linear regression as was demonstrated in [Lee et al, 2007]. See Fig. 3 for all three reconstruction versions with various calibrations and Table 3 for the

Table 3. Statistics of various reconstruction versions (departures in ${ }^{\circ} \mathrm{C}$ )

\begin{tabular}{|l|c|c|c|c|c|}
\hline & $\begin{array}{c}\mathbf{R}^{2} \text { on the } \\
\text { instrumental } \\
\text { period }\end{array}$ & $\begin{array}{c}\text { Lowest } \\
\text { value }\end{array}$ & $\begin{array}{c}\text { Highest } \\
\text { value }\end{array}$ & $\begin{array}{c}\text { Mean over } \\
\text { the recon- } \\
\text { struction }\end{array}$ & $\begin{array}{c}\text { Standard } \\
\text { deviation }\end{array}$ \\
\hline $\begin{array}{l}\text { Calibration based on the effect of Arctic } \\
\text { amplification and minimal values from } \\
\text { the instrumental data }\end{array}$ & 0.6311 & -1.2800 & 1.1484 & -0.1611 & 0.4192 \\
\hline $\begin{array}{l}\text { Calibration on the instrumental period, } \\
\text { linear regression* }\end{array}$ & 0.5410 & -1.0858 & 0.8778 & -0.1770 & 0.3270 \\
\hline $\begin{array}{l}\text { Calibration on the instrumental period, } \\
\text { mean and variance }\end{array}$ & 0.5851 & -1.4584 & 1.1623 & -0.2509 & 0.4524 \\
\hline $\begin{array}{l}\text { Pollen data with dating correction and } \\
\text { without weighting ** }\end{array}$ & 0.6543 & -1.2800 & 1.1230 & -0.1681 & 0.4003 \\
\hline $\begin{array}{l}\text { Pollen data without dating correction } \\
\text { and without weighting ** }\end{array}$ & 0.6461 & -1.2800 & 1.0426 & -0.2031 & 0.4085 \\
\hline
\end{tabular}


coefficient of determination $\left(R^{2}\right)$ for these reconstruction models.

Fig. 3 shows that employing different variants of reconstruction calibration as well as different variants of pollen data preprocessing does not have a very strong impact on the scale of temperature variations and does not at all change a sequence of warm and cold episodes during the whole time span of the study. However, based on the whole body of knowledge concerning the Arctic climate change including the data presented in this paper, we are inclined to recommend for comparative climatic/ historical studies a reconstruction variant based on the Arctic amplification effect and minimum values deduced from the early instrumental data (black line in Fig. 3).

\section{Temperature reconstruction and its characteristics}

A comparison of the final reconstruction with the instrumental record reveals their good correspondence (Fig. 4). The correlation coefficient equals 0,81 for the whole instrumental record since AD 1815, but it reaches 0,91 if we use the instrumental record since $A D$ 1895, when the observations from all the long-term meteorological stations of the region are available (see Fig. 1). The final version of climate history of Northeastern Europe is shown at Fig. 4.

The developed reconstruction shows a high degree of the variability on the multidecadal and centennial timescales. The spectral analysis of the reconstruction was performed by the maximum entropy method (MEM). It revealed statistically significant oscillation modes of the regional temperature with periods of 499, 195, 73, 48, and 24 years (Fig. 5). We argue that the source of the oscillations with the periods around 500 and 200 years, which are apparently global, is the solar activity variation [Klimenko, 1997]. Cycles with these periods are persistently found in time-series of different solar indicators [Fyodorov et al., 1996].

As was shown in our recent study [Klimenko, 2011], a 70-yr periodicity is likely to be attributed to quasiperiodic changes of atmospheric and oceanic circulation to be known as the North-Atlantic Oscillation (NAO) and pulsation of warm water inflow into the Norway and Barents Seas connected to the

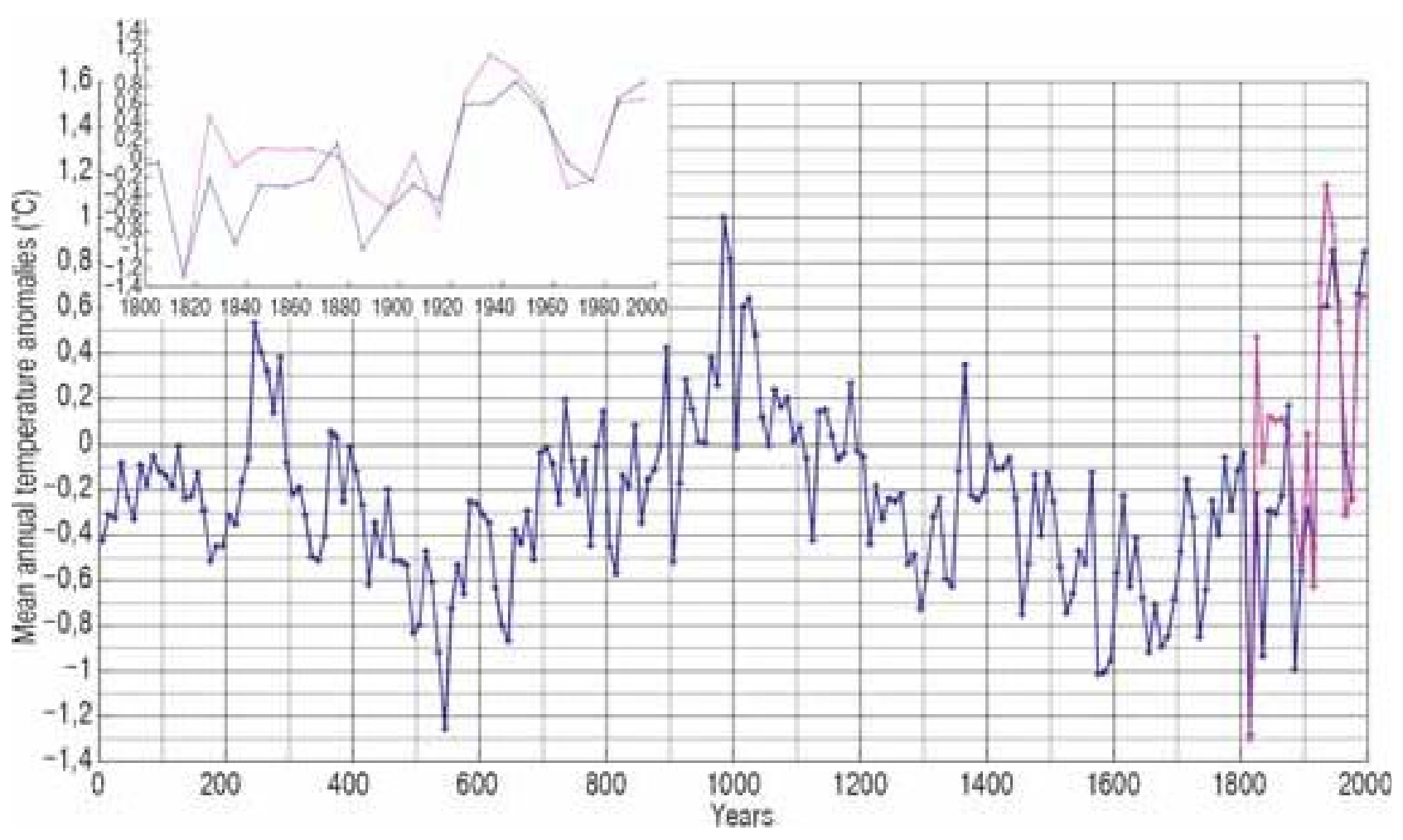

Fig. 4. The final reconstruction of the mean decadal temperature departures for northeastern Europe (blue) and instrumental data (red). The inset denotes the instrumental period. Reference period: 1951-1980 


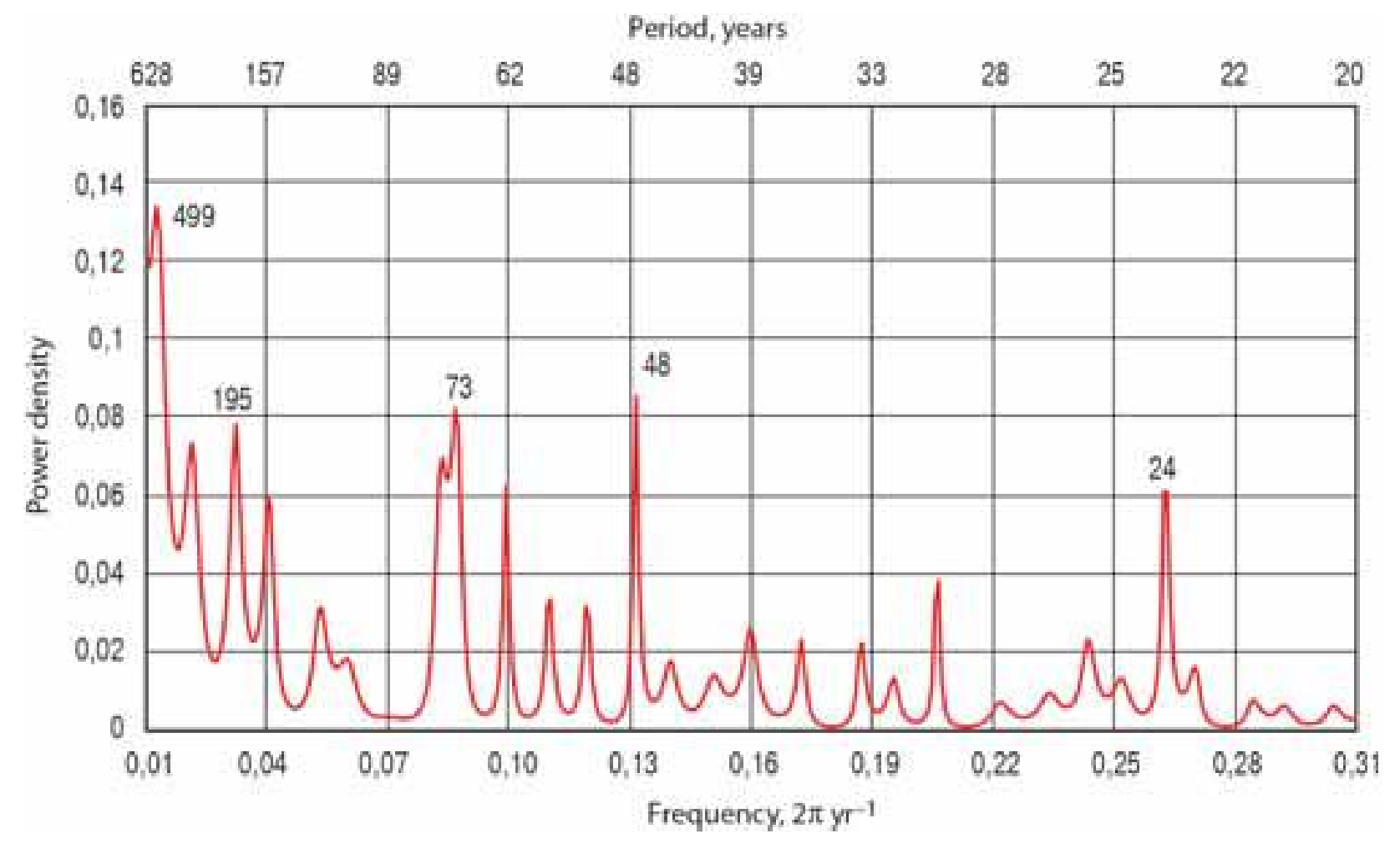

Fig. 5. The power spectral analysis of the final temperature reconstruction. Periods (yr) corresponding to the spectral peaks are shown

NAO (the Atlantic Multidecadal Oscillation, AMO). The same source is likely to explain a 50-yr periodicity - it follows from the results of simulations and reconstructions of the NAO for the last 600 years [Cook et al., 2002].

A bidecadal cycle is usually attributed to the solar forcing, but this explanation can run against some difficulties, because this cycle is well pronounced only in the oceans of the Southern Hemisphere [Klimenko, 2011]. This circumstance urges us to search its origin rather in the dynamics of the Southern Oscillation (SO), whose index has a weak spectral peak of 22 yrs. This assumption is supported by the fact that in the study region, the correlation of meteorological parameters with ENSO events is the strongest for all the extratropical zone of the Northern Hemisphere [Trenberth, 1976].

\section{DISCUSSION}

It is interesting to compare the new mean annual temperature chronology with some other reconstructions. To do this, we used a recent regional reconstruction for the Arctic [Kaufman et al., 2009], as well as reconstructions for the Northern Hemisphere [Moberg et al., 2005, Klimenko, 2009; Esper et al., 2002], and for the Northern Hemisphere extratropical regions $\left(30^{\circ}-90^{\circ} \mathrm{N}\right)$ [Ljungqvist, 2010] (Table 4, Fig. 6).

Table 4. Cross-correlations between various reconstructions

\begin{tabular}{|c|c|c|c|c|c|c|c|}
\hline & $\begin{array}{l}\text { This } \\
\text { work }\end{array}$ & $\begin{array}{l}\text { Moberg } \\
\text { et al., } 2005\end{array}$ & $\begin{array}{c}\text { Klimenko, } \\
2009\end{array}$ & $\begin{array}{l}\text { Esper } \\
\text { et al., } 2002\end{array}$ & $\begin{array}{c}\text { Ljunqvist, } \\
2010\end{array}$ & $\begin{array}{c}\text { Kaufman } \\
\text { et al., } \\
2009\end{array}$ & $\begin{array}{c}\text { Klimenko, } \\
\text { Sleptsov, } \\
2003\end{array}$ \\
\hline This work & 1.000 & 0.648 & 0.437 & 0.593 & 0.627 & 0.545 & 0.306 \\
\hline Moberg et al., 2005 & & 1.000 & 0.222 & 0.457 & 0.509 & 0.270 & 0.115 \\
\hline Klimenko, 2009 & & & 1.000 & 0.288 & 0.492 & 0.354 & 0.701 \\
\hline Esper et al., 2002 & & & & 1.000 & 0.407 & 0.535 & 0.307 \\
\hline Ljunqvist, 2010 & & & & & 1.000 & 0.612 & 0.299 \\
\hline Kaufman et al., 2009 & & & & & & 1.000 & 0.298 \\
\hline Klimenko, Sleptsov, 2003 & & & & & & & 1.000 \\
\hline
\end{tabular}



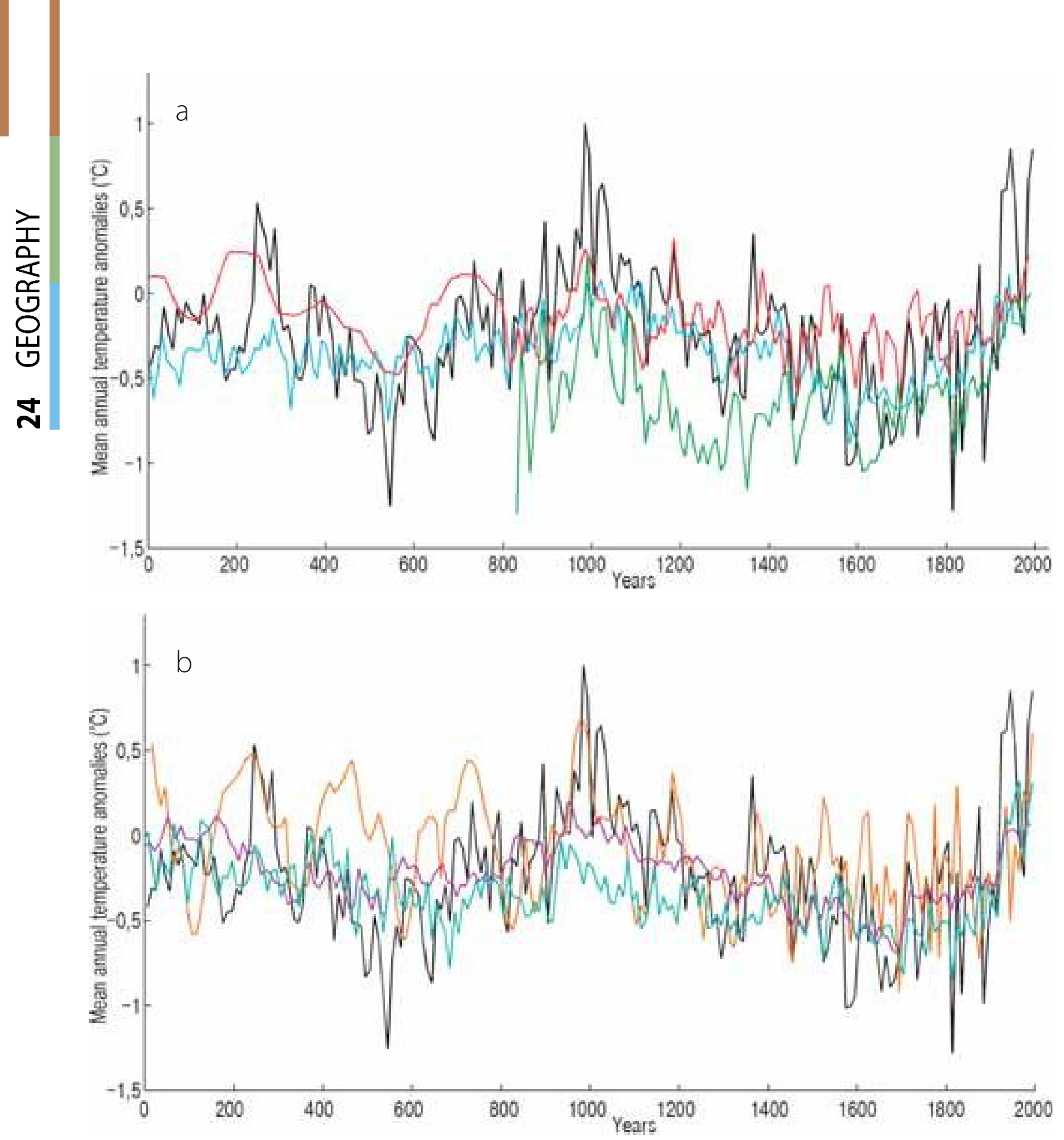

Fig. 6.

a) A comparison of the new chronology for Northeastern Europe (black) with the hemispheric reconstructions of Moberg et al. [2005] (blue), Klimenko [2009] (red) and Esper et al. [2002] (green).

b) A comparison of the new chronology for Northeastern Europe (black) with regional reconstructions: for the extratropical latitudes 30-90 $\mathrm{N}$ [Liungqvist, 2010] (purple), Pan-Arctic [Kaufman et al., 2009] (cyan), and the centre of the Russian Plain [Klimenko, Sleptsov, 2003] (orange). Reference period: 1951-1980

It is obvious that temperature variability in our reconstructions is much higher than in others. This fact agrees with the known effect of Arctic amplification (an increase of temperature variations in high latitude regions as compared to the whole Northern Hemisphere). According to the recent research, the effect of Arctic amplification is in the range from 1,7 to 3,4 [Bekryaev et al., 2010; Miller et al., 2010]. Speaking of the Panarctic reconstruction of Kaufman et al. [2009] (Fig. 6b), one can see that temperature variations are rather moderate. This is due to the difference of temperature variations in the Western and Eastern Arctic, which can be even in antiphase. As our reconstruction corresponds to a relatively small region, all the climatic variations should 
be more pronounced. This is represented by relatively large temperature variations in our reconstruction.

All the reconstructions represent the following major climatic events of the last two millennia: the Roman Optimum $\left(2^{\text {nd }}\right.$ and $3^{\text {rd }}$ centuries), the cold epoch of the Migration Period ( $5^{\text {th }}$ and $6^{\text {th }}$ centuries), the Medieval Warm Period (the $10^{\text {th }}$ to $12^{\text {th }}$ centuries), notable cooling of the Little Ice Age (the $13^{\text {th }}$ through the $19^{\text {th }}$ centuries), and, finally, the modern warm stage $\left(20^{\text {th }}\right.$ century). Often, the reconstructions coincide in details: all of them display pronounced warming at the end of $10^{\text {th }}$ century, notable warmth at the end of the $14^{\text {th }}$ and $18^{\text {th }}$ centuries, sharp cold events of the 1450s and 1810s, etc. The latter events are attributed to large eruptions of Kuwae (1453) and Tambora (1815) volcanoes.

Unlike all the other reconstructions, our chronology displays quick alternations of warm and cold episodes, which are common for high latitudes. A large amplitude of temperature variations (as compared to mid latitudes) leads to an occurrence of rather short warm events (of two to four decades long) even during prolonged cold stages like the Little Ice Age (for example in 13501370, 1400-1440, 1470-1510, 1770-1810 AD). During these periods, temperature has reached and sometimes even exceeded the modern values. These short episodes are of special interest because they are connected with the main impetuses of pioneering and colonization of the Northeastern European margins [Klimenko et al., 2012]. Interestingly, the existence of the last three warm episodes is supported by recent studies based on different proxy data, early instrumental measurements, and numerical simulation [Crespin et al, 2009].

A comparison of our reconstruction with the reconstruction for extratropical latitudes (Fig. 6b) shows a good correspondence of long-period variations. Nevertheless, the absolute minima of the two reconstructions are different: the reconstruction of Ljungqvist
[2010] has its minimum at the boundary between the $17^{\text {th }}$ and $18^{\text {th }}$ centuries, whereas our reconstruction - in the middle of the $6^{\text {th }}$ and in the early $19^{\text {th }}$ century. It can be attributed to different proxy data sets used, as well as to the different geography of the studied regions. For example, a climatic effect of volcanic eruptions is very pronounced in high latitudes while in mid latitudes, an opposite effect (warming) can be observed [Shindell et al., 2004]. This observation can explain the fact that the absolute minimum in our reconstruction occurred in the 1810s during the most powerful volcanic eruption of the last millennium (Tambora, 1815). Other significant cold events also matched the most powerful eruptions (Taupo, AD 177; Rabaul, AD 540; unindentified tropical eruption, AD 639; Ksudach, AD 900; Kuwae, AD 1453; Billy Mitchell, AD 1580; Huaynaputina, AD 1600; Awu, AD 1641; Tarumai, AD 1739; Coseguina, AD 1835; Krakatau, AD 1883; Katmay, AD 1912].

Less pronounced climatic events can differ significantly on a regional scale as is confirmed by the present day climatology [Wanner et al., 2008]. On the global scale, decadal and centennial climate change is probably dominated by radiation factors, while for the Arctic region, circulation factors are often of greater importance [Yamanouchi, 2011].

A comparison of our new reconstruction for Northeastern Europe with the reconstruction for Central Russia [Klimenko, Sleptsov, 2003] also reveals a similar interpretation of large climatic events, such as the Medieval Warm Period, Little Ice Age, and modern warm stage (Fig. 6b). But the Northeastern European chronology displays larger variability and sometimes rather big differences at decadal timescales - for example, warm periods in the late 9th and at the boundary between the $14^{\text {th }}$ and $15^{\text {th }}$ centuries during clearly cool episodes in Central Russia. We believe that these differences are not the shortcomings of any of the two reconstructions but reflect the real variety of climate change episodes in neighboring 
regions. This statement is supported by the instrumental meteorological data of the last two centuries, when such effects were really observed - for example, abrupt warmings of the Arctic region in the 1860-70s and 1920-40s took place during stable and even cool climate stages in Central Russia.

\section{CONCLUSIONS}

In this study, we presented a multi-archive climatic chronology for Northeastern Europe based on various proxy data: treering, pollen/lake sediment, and historical. We think it correctly represents the climatic history of this region for the last two millennia and can be used to elaborate a comparative chronology of climatic and historical events which has been conducted in our recent work [Klimenko et al, 2012]. Five different versions of temperature reconstruction were developed and one of them may be considered the base-case, because it, to a maximum possible extent, accumulates knowledge concerning the Northeastern European climate change in the contemporary epoch, historical period, as well as on the geological time scale. The comparison of our new reconstruction of decadal mean annual temperature with some other regional and hemispheric reconstructions shows that such large-scale climatic events as the Roman Optimum ( $2^{\text {nd }}$ $3^{\text {rd }}$ centuries $A D$ ), subsequent cooling of the Great Migration Period (5-6 th centuries AD), the Medieval Warm Epoch (10-12 ${ }^{\text {th }}$ centuries AD), the Little Ice Age (13-19th centuries AD), and the present warm stage (20 th century) are evident both on the hemispheric and regional scales. But less significant decadal and multidecadal climatic variations on a regional scale can substantially differ from the whole climatic picture on the hemispheric scale. Our reconstruction reveals a larger variance amplitude compared to the other reconstructions. We attribute this feature on one hand, to the Arctic amplification effect and, on the other hand, to a relatively small size of the study area, where climatic variations are nearly synchronous and do not cancel each other when averaged over the region.

\section{ACKNOWLEDGEMENTS}

We would like to thank the Alexander von Humboldt Foundation (Germany) for continuing support. The study was partly funded by the Grant of President of the Russian Federation MK-7354.2013.5.

\section{REFERENCES}

1. Aimers J., Hodell D. (2011) Societal collapse: Drought and the Maya. // Nature. Vol. 479. No. 7371. P. 44-45.

2. Andreev A.A., Klimanov V.A. (2000) Quantitative Holocene climatic reconstruction from Arctic Russia. // J. Paleolimnol., Vol. 24. No. 1. P. 81-91.

3. Bekryaev R.V., Polyakov I.V., Alexeev V.A. (2010) Role of polar amplification in long-term surface air temperature variations and modern Arctic warming. // J. Climate. Vol. 23. No. 14. P. 3888-3906.

4. Bbntgen U., Tegel W., Nicolussi K., McCormick M., Frank D., Trouet V., Kaplan J.O., Herzig F., Heussner K.-U., Wanner H., Luterbacher J., Esper J. (2011) 2500 years of European climate variability and human susceptibility. // Science. Vol. 331. No. 6017. P. 578-582.

5. Cook E.R., D'Arrigo R.D., Mann M.E. (2002) A well- verified, multiproxy reconstruction of the winter North Atlantic Oscillation Index since A.D. 1400 // J. of Climate. Vol. 15. No. 13. P. 1754-1764. 
6. Crespin E., Goosse H., Fichefet T. and Mann M.E. (2009) The 15th century Arctic warming in coupled model simulations with data assimilation // Climates of the Past. Vol. 5. No. 3. P. 389-401.

7. Esper J., Cook E.R., Schweingruber F.H. (2002) Low-frequency signals in long tree-ring chronologies for reconstructing past temperature variability. // Science. Vol. 295. No. 5563. P. 2250-2253.

8. Fyodorov M.V., Klimenko V.V. and Dovgalyuk V.V. (1996) Sunspot minima dates: A secular forecast // Solar Physics. Vol. 165. No. 1. P. 193-199.

9. Gurskaya M., Hallinger M., Singh J., Agafonov L., Wilmking M. (2012) Temperature reconstruction in the Ob River valley based on ring widths of three coniferous tree species // Dendrochronologia. Vol. 30. No. 4. P. 302-309.

10. Hantemirov R.M., Shiyatov S.G. (2002) A continuous multimillennial ring-width chronology in Yamal, northwestern Siberia. // The Holocene. Vol. 12. No. 6. P. 717-726.

11. Jones P.D., Briffa K.R., Osborn T.J., Lough J.M., van Ommen T.D., Vinther B.M., Luterbacher J., Wahl E.R., Zwiers F.W., Mann M.E., Schmidt G.A., Ammann C.M., Buckley B.M., Cobb K.M., Esper J., Goosse H., Graham N., Jansen E., Kiefer T., Kull C., Kbttel M., Mosley-Thompson E., Overpeck J.T., Riedwyl N., Schulz M., Tudhope A.W., Villalba R., Wanner H., Wolff E., Xoplaki E. (2009) High-resolution palaeoclimatology of the last millennium: a review of current status and future prospects. // The Holocene. Vol. 19. No. 1. P. 3-49.

12. Kaufman D.S., Schneider D.P., McKay N.P., Ammann C.M., Bradley R.S., Briffa K.R., Miller G.H., Otto-Bliesner B.L., Overpeck J.T., Vinther B.M., Arctic Lakes 2k Project Members (2009) Recent Warming Reverses Long-Term Arctic Cooling. // Science. Vol. 325. No. 5945. P. 1236-1239.

13. Klimanov V.A., Khotinsky N.A., Blagoveschenskaya N.V. (1995) Variations of climate of the Russian Plain during the historical period // Izvestia RAN. Ser. geogr. No. 1. P. 89-96 (in Russian).

14. Klimenko V.V. (1997) On major climatic cycles of Holocene. // Transactions of the Russian Academy of Sciences / Earth Science Sections. 1997. Vol. 357A, No. 9. P. 1339-1342 (in Russian).

15. Klimenko V.V. (2009) Climate: Lost Chapter of the World History. Moscow: MEl Publ (in Russian).

16. Klimenko V.V. (2010) A Composite Reconstruction of the Russian Arctic Climate Back to A.D. 1435. // In: The Polish Climate in the European Context: An Historical Overview. Eds. Przybylak, R., Majorowicz, J., Br6zdil R., Kejna M., Berlin: Springer. Chapter 3. P. 295-326.

17. Klimenko V.V. (2011) Why Is Global Warming Slowing Down? // Doklady Earth Sciences. 2011. Vol. 440. Part 2. P. 1419-1422 (in Russian).

18. Klimenko V.V., Matskovsky V.V., Pakhomova L.Yu. (2012) High latitudes climate variations and pioneering of Northeastern Europe in the Middle Ages // History and Modernity. No. 2. P. 130-163 (in Russian).

19. Klimenko V.V., Sleptsov A.M. (2003) Complex reconstruction of climate of East Europe over the last 2,000 years. // Izvestia RGO. No. 6. P. 45-53 (in Russian). 
20. Lee T.C.K., Zwiers F.C. and Tsao M. (2008) Evaluation of proxy-based millennial reconstruction methods // Clim. Dyn. Vol. 31. No. 2-3. P. 263-281.

21. Ljungqvist F.C. (2010) A new reconstruction of temperature variability in the extra-tropical Northern Hemisphere during the last two millennia. // Geogr. Ann. Vol. 92A. No. 3. P. 339-351.

22. Miller G.H., Alley R.B., Brigham-Grette J., Fitzpatrick J.J., Polyak L., Serreze M.C., White J.W.C. (2010) Arctic amplification: can the past constrain the future? // Quaternary Science Reviews. Vol. 29. No. 15-16. P. 1779-1790.

23. Moberg A., Sonechkin D.M., Holmgren K., Datsenko N.M., Karlen W. (2005) Highly variable Northern Hemisphere temperatures reconstructed from low- and high-resolution proxy data. // Nature. Vol. 433. No. 7026. P. 613-617.

24. Naurzbaev M.M., Vaganov E.A., Sidorova O.V., Schweingruber F.H. (2002) Summer temperatures in eastern Taimyr inferred from a 2427-year late-Holocene tree-ring chronology and earlier floating series. //The Holocene. Vol. 12. No. 6. P. 727-736.

25. Peterson T.C., Vose R.S. (1997) An overview of the Global Historical Climatology Network temperature database // Bulletin of the American Meteorological Society, Vol. 78. No. 12. P. 2837-2849.

26. Reimer P.J., Baillie M.G.L., Bard E., Bayliss A., Beck J.W., Blackwell P.G., Bronk Ramsey C., Buck C.E., Burr G.S., Edwards R.L., Friedrich M., Grootes P.M., Guilderson T.P., Hajdas I., Heaton T.J., Hogg A.G., Hughen K.A., Kaiser K.F., Kromer B., McCormac F.G., Manning S.W., Reimer R.W., Richards D.A., Southon J.R., Talamo S., Turney C.S.M., van der Plicht J., Weyhenmeyer C.E. (2009) IntCal09 and Marine09 Radiocarbon Age Calibration Curves, 0-50,000 Years cal BP. // Radiocarbon. Vol. 51. No. 4. P. 1111-1150.

27. Shindell D.T., Schmidt G.A., Mann M.E., Faluvegi G. (2004) Dynamic winter climate response to large tropical volcanic eruptions since 1600 // J. Geophys. Res. Vol. 109. No. D05104. doi:10.1029/2003JD004151.

28. Trenberth K.E. (1976) Spatial and temporal variations of the Southern Oscillation // Quart. J. Royal Met. Soc. Vol. 102. No. 433. P. 639-653.

29. Velichko, A.A., Andreev A.A., Klimanov V.A. (1997) Climate and vegetation dynamics in the tundra and forest zone during the Late Glacial and Holocene. // Quaternary Int. Vol. 41/42. P. 71-96.

30. Wanner H., Beer J., Butikofer J., Crowley T.J., Cubasch U., Fluckiger J., Goosse H., Grosjean M., Joos F., Kaplan J.O., Kuttel M., Muller S.A., Prentice I.C., Solomina O., Stocker T.F., Tarasov P., Wagner M., Widmann M. (2008) Mid- to Late Holocene climate change: an overview. // Quaternary Science Reviews. Vol. 27. No. 19-20. P. 1791-1828.

31. Winton M. (2006) Amplified Arctic climate change: What does surface albedo feedback have to do with it? // Geophys. Res. Lett. Vol. 33. L03701. doi:10.1029/2005GL025244

32. Yamanouchi T. (2011) Early $20^{\text {th }}$ century warming in the Arctic: A review. // Polar Science. Vol. 5. No. 1. P. 53-71. 


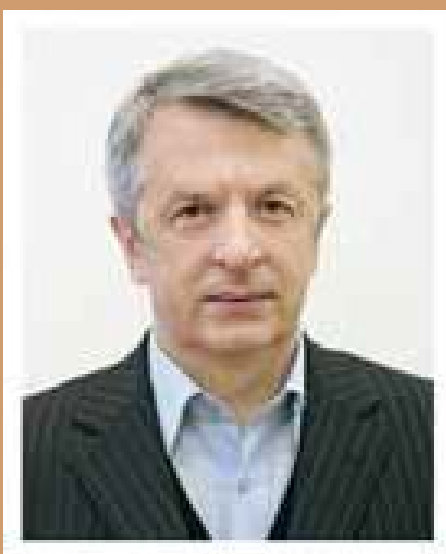

Vladimir Klimenko is Full Professor and Head of Global Energy Laboratory at Moscow Power Engineering Institute. He received his Ph.D. degree in 1975 and D.Sc. degree in 1985 in thermal physics. His research interests are associated with energy and environment interaction, global climate change, palaeoclimatology, climate influence on social history, driving forces of the historical process. Main Publications: Climate of the Medieval Warm Epoch in the Northern Hemisphere (2001); Cold Climate of the Early Subatlantic Epoch in the Northern Hemisphere (2004); Climate: Lost Chapter of the World History (2009); A Composite Reconstruction of the Russian Arctic Climate Back to A.D. 1435 (2010).

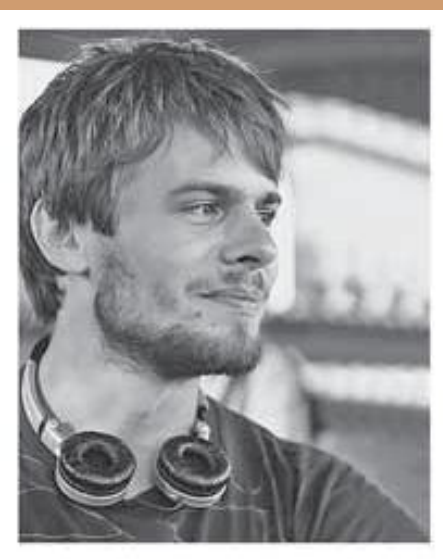

Vladimir Matskovsky is Scientific Researcher at the Institute of Geography, Russian Academy of Sciences. He graduated in 2008 with diploma in computer science and received his Ph.D. in paleogeography in 2011. His main research interests are dendrochronology, dendroclimatology, and high resolution climate reconstructions. He participated in numerous expeditions to different parts of Russia. He is Principal Investigator of two research projects and the author and co-author of more than 20 papers and 1 monograph.

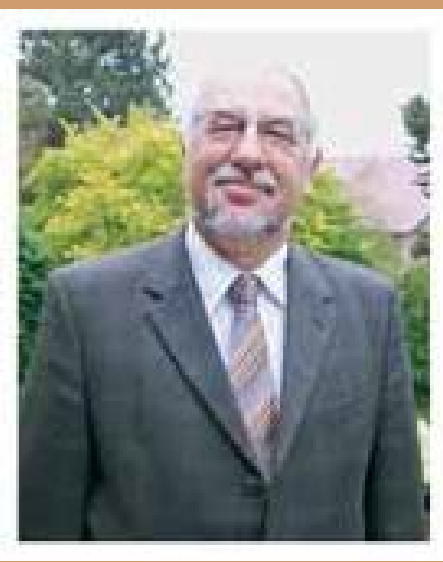

Dittmar Dahlmann is Full Professor and Head of the Department of East European History at the Rheinische Friedrich-WilhelmsUniversitgt, Bonn. He received his Ph.D. degree in 1983 and his Habilitation in 1994. His research interests are in the history of Siberia and in the history of Science in the $18^{\text {th }}$ and $19^{\text {th }}$ centuries. Main Publications: Sibiren vom 16. Jahrhundert bis zur Gegenwart (2009); Carl Heinrich Merck. Das sibirischamerikanische Tagebuch aus den Jahren 1788-1791 (2009, eds). 